\title{
Bioremediasi Lumpur Minyak (Oil Sludge) dengan Penambahan Kompos sebagai Bulking Agent dan Sumber Nutrien Tambahan
}

\author{
Any Juliani dan Fudhola Rahman \\ Environmental Engineering Universitas Islam Indonesia \\ Jl. Kaliurang Km 14,4 Yogyakarta 55581 \\ email: any.juliani@staff.uii.ac.id
}

\begin{abstract}
Abstrak
Bioremediasi merupakan salah satu alternatif pengolahan limbah berbahaya yang relatif lebih ekonomis, mudah dan ramah lingkungan. Teknologi ini memanfaatkan aktivitas mikroba untuk mengolah limbah berbahaya tadi menjadi lebih rendah bahayanya atau bahkan tidak berbahaya sama sekali. Salah satu limbah yang berpotensi menjadi limbah berbahaya dari aktivitas industri adalah limbah oil sludge. Oil sludge memiliki karakteristik tertentu sehingga untuk proses bioremediasinya perlu dicampur dengan tanah. Pencampuran dengan tanah bertujuan untuk memperbaiki porositas bahan sehingga pertukaran oksigen dapat berlangsung lebih baik. Oksigen diperlukan mikroba untuk penguraian limbah. Selain oksigen, mikroba juga memerlukan nutrien penunjang yang minim disediakan oleh lingkungan. Kompos mempunyai kemampuan untuk meningkatkan porositas, merupakan bahan nutrien tambahan bagi mikroba serta sumber mikroba yang sangat kaya. Oleh karena itu, kompos dapat ditambahkan pada proses bioremediasi untuk mendapatkan hasil yang lebih baik. Penelitian ini bertujuan untuk mengetahui pengaruh penambahan kompos pada bioremediasi oil sludge PT Pertamina Cilacap. Selain itu diteliti juga porsi penambahan kompos dan proporsi tanah dan oil sludge yang dapat memberikan hasil degradasi oil sludge terbaik. Berdasarkan hasil penelitian, kompos memberikan pengaruh positif terhadap proses bioremediasi. Reaktor yang diberi kompos lebih banyak yaitu sebanyak 10\% memberikan angka penurunan Total Petroleum Hydrocarbon (TPH) yang lebih baik dari reaktor yang hanya diberi 5\% kompos. Kompos pada penelitian ini lebih berperan sebagai bulking agent serta sumber nutrien tambahan dibanding sebagai penyumbang mikroba pendegradasi. Mikroba yang berperan lebih banyak selama proses adalah mikroba indigenous dari limbah oil sludge. Hasil terbaik juga diberikan oleh reaktor dengan proporsi tanah dan oil sludge yang sama. Efisiensi penurunan TPH tertinggi adalah sebesar 39\% selama 21 hari.
\end{abstract}

Kata kunci: oil sludge, bioremediasi, kompos, TPH, bulking agent, nutrien, degradasi microbial

\section{Pendahuluan}

Bioremediasi merupakan teknologi pengolahan limbah berbahaya dengan memanfaatkan aktivitas mikroorganisme. Teknologi ini dianggap cukup efektif, relatif murah serta ramah lingkungan. Salah satu aplikasi teknologi bioremediasi diantaranya adalah untuk pemulihan lingkungan akibat pencemaran minyak bumi baik dari aktivitas pertambangan maupun pemurniannya. Salah satu jenis limbah yang dihasilkan oleh aktivitas tersebut adalah lumpur minyak (oil sludge).

Bioremediasi lumpur minyak dilakukan dengan mencampurkan lumpur minyak tersebut dengan tanah. Hal ini bertujuan untuk memperbaiki porositas dari limbah. Porositas media sangat penting terutama untuk pertukaran oksigen yang baik. Suplai oksigen yang cukup memungkinkan mikroba dapat bekerja secara optimal mendegradasi pencemar. Keberhasilan proses bioremediasi juga sangat 
tergantung dari ketersediaan nutrien serta kondisi lingkungan diantaranya $\mathrm{pH}$ yang baik bagi mikroba. Kandungan dalam kompos sangat baik untuk tujuan tersebut. Selain itu, tekstur kompos juga dapat turut membantu meningkatkan porositas campuran tanah dan lumpur minyak. Berdasarkan pemikiran ini, proporsi campuran tanah yang tepat serta penambahan kompos diharapkan dapat meningkatkan kinerja proses bioremediasi.

Penelitian ini dilakukan untuk mengetahui pengaruh penambahan kompos serta proporsi campuran tanah dan lumpur minyak terbaik. Perlakuan ini diharapkan dapat menstimulasi mikroba indigenous sehingga dapat bekerja optimal mendegradasi limbah lumpur minyak ini. Hasil penelitian diharapkan dapat memberikan masukan atau pilihan teknik bioremediasi yang dapat dilakukan untuk mengatasi timbulan limbah lumpur minyak.

\section{Metode Penelitian}

\section{Tahapan penelitian}

Penelitian dilakukan melalui tahapan sebagai berikut:

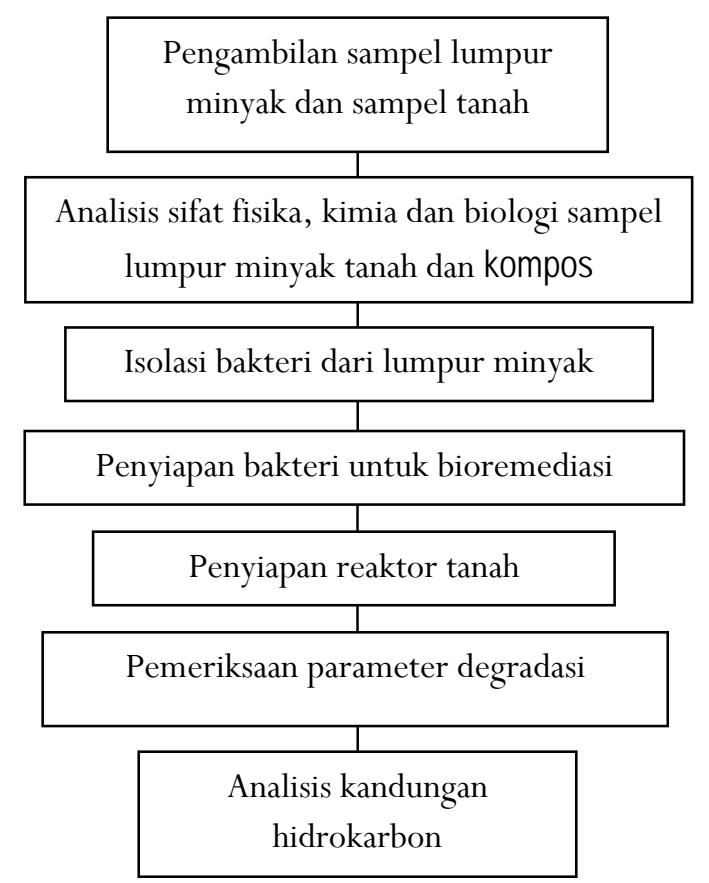

Gambar 1. Tahapan penelitian

1. Pengambilan sampel lumpur minyak dan tanah

Sampel lumpur minyak diambil dari kawasan kilang minyak PT Pertamina UP IV Cilacap. Sedangkan sampel tanah untuk campuran dalam reaktor diambil dari sekitar kampus terpadu UII. 
2. Analisis sifat lumpur minyak dan tanah serta kompos

Sebelum digunakan untuk media dalam reaktor tanah, sampel lumpur minyak dan tanah serta kompos terlebih dahulu dianalisis sifat fisika, kimia dan biologinya.

Parameter fisika yang diperiksa adalah kadar air, densitas, porositas, void ratio, derajat saturasi, analisis ayakan tanah dan spesific gravity tanah. Analisis dilakukan di laboratorium Mekanika Tanah, Jurusan Teknik Sipil, UII.

Analisis kimia tanah dilakukan di Laboratorium Kimia dan Kesuburan Tanah Fakultas Pertanian UGM. Parameter yang diperiksa adalah C-organik, N-total, pH, P-total, Kalium dan KTK. Selain parameter-parameter di atas dilakukan pula analisis kandungan TPH dari sampel untuk mengetahui kandungan hidrokarbon awal.

Analisis biologi dilakukan dengan mengambil 1 gram sampel tanah yang dilarutkan dalam 9 ml aquades steril, kemudian dilakukan pengenceran hingga $10^{-5}$. Sebanyak $1 \mathrm{ml}$ sampel yang telah diencerkan dimasukkan ke dalam cawan petri steril. Penanaman bakteri dilakukan dengan metode pour-plate menggunakan media NA (sebagai media umum bakteri) untuk mengetahui keberadaan bakteri heterotrof (Gaudy \& Gaudy, 1980).

3. Isolasi bakteri dari lumpur minyak

Hal ini dilakukan untuk mendapatkan isolat bakteri untuk proses bioremediasi. Langkah pengerjaannya sama seperti analisis biologis sampel. Media cari yang digunakan adalah media Standard Basal Salt (SBS) dengan komposisi 1,5 gr $\mathrm{K}_{2} \mathrm{HPO}_{4} ; 0,5$ gr $\mathrm{KH}_{2} \mathrm{PO}_{4} ; 0,5$ gr $\left(\mathrm{NH}_{4}\right)_{2} \mathrm{SO}_{4}$ dan 0,2 gr $\mathrm{MgSO}_{4}$ (Effendi, 1999). Bakteri yang telah ditumbuhkan dalam media padat diinkubasi \pm 7 hari.

4. Penyiapan bakteri untuk bioremediasi

Hal ini dilakukan agar mikroba yang terlibat dalam bioremediasi di setiap sel pengamatan memiliki kondisi yang sama untuk melakukan degradasi sehingga perbedaan yang terukur terjadi karena perbedaan perlakuan (variasi). Bakteri disiapkan dengan cara isolat yang telah disiapkan pada langkah sebelumnya dipindahkan pada media cair. Isolat yang diinokulasikan merupakan konsorsium bakteri yang ada dalam sampel lumpur minyak. Selanjutnya dilakukan pemeriksaan OD (optical density) untuk dicari awal fase stasionernya. Fase ini adalah fase dimana jumlah sel paling banyak dan siap untuk dipindahkan ke reaktor tanah.

5. Penyiapan reaktor tanah

Reaktor tanah yang dipakai dalam penelitian ini adalah berupa kontainer plastik berdiameter 15 $\mathrm{cm}$ dan tinggi $10 \mathrm{~cm}$. Kontainer tersebut diisi dengan campuran sampel tanah dengan lumpur 
minyak dengan berat total campuran \pm 200 gram. Sebelum dimasukkan ke dalam sel, campuran tanah dan lumpur minyak telah diayak dengan ayakan berukuran $2 \mathrm{x} 2 \mathrm{~mm}^{2}$ dan telah dikeringkan dalam oven $105^{\circ} \mathrm{C}$ sampai beratnya konstan. Proporsi campuran tanah dan lumpur minyak ada 2 variasi yaitu 25\% dan 50\% lumpur minyak. Selanjutnya $50 \mathrm{ml}$ inokulum bakteri yang telah disiapkan di tahap sebelumnya ditambahkan pada masing-masing reaktor kecuali reaktor kontrol K1 dan K2.

Masing-masing reaktor tanah dibuat duplo dan terdiri dari:

a. Reaktor kontrol (K1) yaitu tanah + lumpur minyak dengan proporsi $1: 1$

b. Reaktor kontrol (K2) yaitu tanah + lumpur minyak dengan proporsi $3: 1$

c. Reaktor uji pengaruh penambahan pupuk kompos dengan variasi sebagai berikut:

- A: tanah + lumpur minyak (1:1) + kompos 5\% (b/b)

- $\quad$ B: tanah + lumpur minyak (1:1) + kompos $10 \%(b / b)$

- C: tanah + lumpur minyak (3:1) + kompos 5\% (b/b)

- $\quad$ D: tanah + lumpur minyak (3:1) + kompos 10\% (b/b)

Semua reaktor tanah diaerasi dengan cara diaduk setiap hari. Temperatur pengamatan adalah temperatur ruang. Pengamatan dilakukan selama 3 minggu. Parameter-parameter yang diuji selama proses adalah:

1. Pengukuran $\mathrm{pH}$

Pengukuran $\mathrm{pH}$ dilakukan dengan mengambil 5 gram sampel tanah lalu dilarutkan dalam aquades dengan rasio tanah:aquades $=1: 2.5$ (b/v) (Rump \& Weinheim, 1992). Sampel ditempatkan dalam tabung reaksi bertutup, lalu dikocok agar homogen. Sampel didiamkan selama 1 jam, kemudian diukur dengan menggunakan $\mathrm{pH}$ meter.

2. Pengukuran TPH (Total Petroleum Hydrocarbon) (Greenberg, 1992)

Pengukuran TPH dilakukan dengan prinsip gravimetri. Sebanyak 5 gram sampel tanah ditimbang dan dimasukkan ke dalam vial bertutup. Dilakukan ekstraksi terhadap sampel tanah dengan menggunakan $10 \mathrm{ml}$ n-hexane sebagai zat pengekstraksi. Ekstraksi dilakukan 2 kali untuk mendapatkan kandungan hidrokarbon lebih baik. Vial yang berisi 5 gram tanah dan $10 \mathrm{ml}$ n-hexane ditutup rapat, kemudian di-shaker selama 2 jam (ekstraksi pertama). Supernatannya kemudian disaring dengan menggunakan kerta filter untuk menghindari terbawanya partikel-partikel tanah. Filtrat ditampung di vial lainnya yang telah ditimbang. 
Sebelum digunakan, vial telah dikeringkan terlebih dahulu di oven $105^{\circ} \mathrm{C}$, lalu dimasukkan ke dalam desikator selama 30 menit, sehingga diperoleh berat awal vial. Vial yang berisi filtrat tersebut kemudia dipanaskan pada hotplate $\left(\mathrm{T}=70^{\circ} \mathrm{C}\right)$ sampai seluruh hexane menguap (tinggal ekstraknya yang berupa minyak). Ekstraksi kedua dilakukan seperti ekstraksi pertama, selama 2 jam. Total berat minyak (TPH) yang diekstrak dapat diperoleh dengan menghitung selisih berat vial awal dan akhir.

$\mathrm{TPH}(\% \mathrm{~b} / \mathrm{b})=((\mathrm{A}-\mathrm{B}) \mathrm{gr} / 5$ gram $) \times 100 \%$

A = berat vial akhir (dengan minyak hasil ekstraksi)

B = berat vial awal (sebelum ekstraksi)

3. Perhitungan jumlah sel bakteri (Total Plate Count)

Sampel tanah yang diambil untuk analisis TPC adalah sebanyak 1 gram. Sampel tanah tersebut dilarutkan dalam $9 \mathrm{ml}$ aquades steril, kemudian dilakukan pengenceran sampel. Sebanyak $1 \mathrm{ml}$ sampel hasil pengenceran, dimasukkan ke dalam cawan petri steril dan ditumbuhkan di media NA steril dengan metode pour plate.

4. Pengukuran kadar air

Dilakukan dengan mengambil sampel tanah sebanyak 5 gram ditempatkan dalam cawan pijar. Kadar air dihitung berdasarkan selisih berat cawan awal dan akhir (setelah dimasukkan ke dalam oven $105^{\circ} \mathrm{C}$ ). Kadar air yang diukur dapat berdasarkan berat material basah (berat basah) atau material kering (berat kering).

Kadar air $(\%)=(a-b) / a$

$\mathrm{a}=$ massa sampel awal

$\mathrm{b}=$ massa sampel setelah dikeringkan

Pengukuran terhadap seluruh parameter dilakukan setiap 7 hari.

6. Analisis kandungan hidrokarbon

Pada akhir masa pengamatan dilakukan analisis menggunakan GC untuk mengetahui perubahan komponen minyak bumi setelah proses (degradasi). Analisis dengan GC dilakukan pada sampel tanah dengan tingkat degradasi terbaik. Analisis dilakukan di Laboratorium Penelitian dan Pengujian Terpadu, Universitas Gadjah Mada. 


\section{Hasil dan Pembahasan}

\section{Isolasi dan Pembenihan Mikroba}

Isolasi bakteri dengan metode pour-plate menggunakan media NA (Nutrien Agar) sebagai nutrisi bagi bakteri agar dapat tumbuh dan berkembang dengan baik. Isolat yang telah tumbuh dipindahkan ke media cair SBS (Standard Basal Salt) yang selanjutnya akan disiapkan sebagai inokulum untuk reaktor penelitian yang sebenarnya. Inokulum dipindahkan pada saat awal fase stasioner sehingga diharapkan kondisi inokulum sudah stabil dan cukup merata untuk semua reaktor. Awal fase stasioner diketahui melalui pemeriksaan OD (Optical Density). Fase pertumbuhan terjadi antara 2,5- 12 jam sebab pada saat 12 jam konsentrasi massa sel telah mencapai titik maksimum. Oleh karena itu, setelah 12 jam kultur dianggap telah memasuki fase stasioner. Hasil pembacaan absorbansi dari spektrofotometer dengan panjang gelombang $600 \mathrm{~nm}$, terdapat pada Tabel 1 .

Tabel 1. Hasil pembacaan absorbansi spektrofotometer

\begin{tabular}{|c|c|}
\hline $\begin{array}{c}\text { Waktu } \\
\text { (jam) }\end{array}$ & $\begin{array}{c}\text { Absorbansi } \\
\text { (A) }\end{array}$ \\
\hline 0 & 0.005 \\
\hline 2 & 0.007 \\
\hline 4 & 0.295 \\
\hline 6 & 0.295 \\
\hline 8 & 0.294 \\
\hline 10 & 0.3 \\
\hline 11 & 0.3 \\
\hline 12 & 0.293 \\
\hline 13 & 0.286 \\
\hline 14 & 0.267 \\
\hline 15 & 0.245 \\
\hline
\end{tabular}

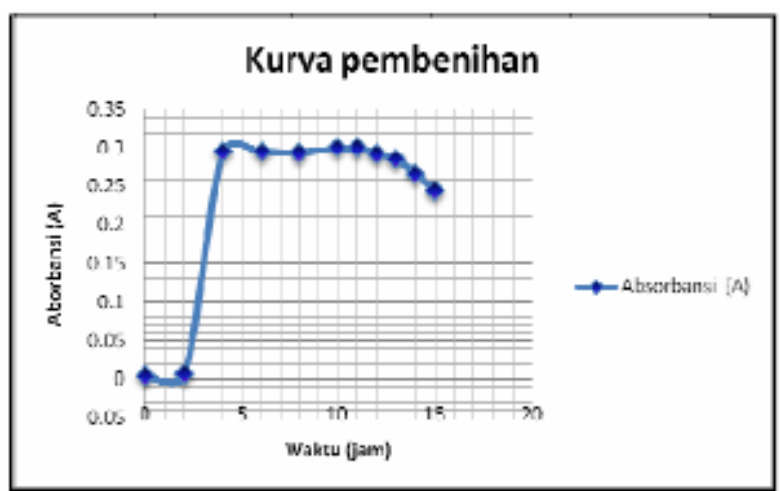

Gambar 2. Kurva pembenihan

\section{Analisis Sifat Lumpur Minyak (Oil sludge) dan Tanah}

a. Analisis Sifat Fisika dan Kimia

Hasil analisis sifat fisika dan kimia terhadap tanah dan campuran tanah dan oil sludge adalah sebagai berikut: 
Tabel 2. Hasil analisis fisika tanah dan lumpur minyak

\begin{tabular}{|l|c|c|c|}
\hline \multicolumn{1}{|c|}{ Hasil analisa } & Tanah & $\begin{array}{c}\text { Tanah dan Oil } \\
\text { Sludge 1 : 1 }\end{array}$ & $\begin{array}{c}\text { Tanah dan Oil } \\
\text { Sludge 3 : 1 }\end{array}$ \\
\hline Kadar air (w) & $32,67 \%$ & $2,95 \%$ & $15,76 \%$ \\
\hline Spesific gravity $(\mathrm{Sg})$ & 2,51 & 1,47 & 1,45 \\
\hline Porositas $(\mathrm{n})$ & $61,02 \%$ & $7,86 \%$ & $18,18 \%$ \\
\hline Derqjat saturasi & 1,59 & 0,51 & 1,03 \\
\hline Void ratio $(\mathrm{e})$ & 1,57 & 0,09 & 0,22 \\
\hline Densitas $(\gamma)$ & $1,30 \mathrm{gr} / \mathrm{cm}^{3}$ & $1,39 \mathrm{gr} / \mathrm{cm}^{3}$ & $1,37 \mathrm{gr}^{3} \mathrm{~cm}^{3}$ \\
\hline
\end{tabular}

Tabel 3. Hasil analisis sifat kimia tanah

\begin{tabular}{|c|l|c|c|}
\hline No & \multicolumn{1}{|c|}{ Variabel analisa } & Satuan & $\begin{array}{c}\text { Konsentrasi } \\
\text { Variabel }\end{array}$ \\
\hline 1 & C-organik & $\%$ & 0,32 \\
\hline 2 & N-total & $\%$ & 0,16 \\
\hline 3 & P-total & $\%$ & 0,07 \\
\hline 4 & Kalium & $\%$ & 0,05 \\
\hline 5 & KTK (Kapasitas Tukar Kation) & $\mathrm{me} / 100 \mathrm{gr}$ & 17,30 \\
\hline 6 & $\mathrm{pH}$ & $\mathrm{H}_{2} \mathrm{O}$ & 6,54 \\
\hline 7 & BO (baban organil) & $\%$ & 0,55 \\
\hline
\end{tabular}

Tabel 4. Hasil analisis sifat kimia oil sludge

\begin{tabular}{|c|l|c|c|c|}
\hline No & $\begin{array}{c}\text { Variabel } \\
\text { analisa }\end{array}$ & Satuan & Metode & $\begin{array}{c}\text { Konsentrasi } \\
\text { Variabel }\end{array}$ \\
\hline 1 & C-organik & $\%$ & A.AS-Flame & 45,22 \\
\hline 2 & N-total & $\%$ & Kjeldabl & 0,52 \\
\hline 3 & P-total & $\%$ & Spektro UV-Vis & 0,02 \\
\hline 4 & kalium & $\%$ & Gravimetri & 0,05 \\
\hline 5 & Air & $\%$ & Destilasi & 4,72 \\
\hline 6 & $\mathrm{pH}(\mathrm{T})$ & $\mathrm{H}_{2} \mathrm{O}\left(29,7^{\circ}\right)$ & potensiometri & 5,21 \\
\hline
\end{tabular}

Kadar air tanah selalu dinyatakan dalam persen dan nilainya dapat berkisar dari 0\% sampai 200\% 300\%. Pada tanah dalam keadaan aslinya kadar air biasa adalah dari 15\% sampai 100\%. (Wesley, 1977). Sedangkan pada Tabel 2 di atas dapat diamati kadar air sebesar 32.67\%. Untuk bioremediasi oil sludge dengan penambahan kompos, kadar air untuk mengoptimalkan proses degradasi hidrokarbon tidak boleh melebihi 60\% (Cookson, 1995). Karena keterbatasan persediaan air untuk metabolisme dan pertumbuhan mikroba merupakan penyebab lain dari keterbatasan biodegradasi hidrokarbon di lingkungan tanah.

Berat volume tanah (densitas) ditentukan dalam $\mathrm{gr} / \mathrm{cm}^{3}$ sama dengan $\mathrm{kg} / \mathrm{cm}^{3}$. Berat volume tanah dibagi dua yaitu berat volume tanah basah dan berat volume tanah kering. Tanah yang tergolong gembur yaitu tanah yang memiliki konsentrasi berat volume tanah basahnya adalah dari 1,6 sampai 2,0 kg/ $\mathrm{cm}^{3}$ dan 0,6 sampai 2,4 kg/cm³ untuk konsentrasi berat volume keringnya (Wesley, 1977). Di dalam tabel konsentrasi densitas basah dan densitas kering yaitu 1,3 gr/ $\mathrm{cm}^{3}$ dan $0,98 \mathrm{gr} / \mathrm{cm}^{3}$. Jika 
densitas tanah dihubungkan dengan proses bioremediasi, untuk tanah yang digunakan dapat disimpulkan termasuk tanah yang gembur dan baik untuk digunakan pada penelitian ini.

Porositas merupakan karakteristik tanah penting yang berpengaruh pada interaksi antara kontaminan pencemar dengan kadar air. Berdasarkan hasil analisis fisika, porositas tanah yang digunakan pada penelitian adalah 61,02\%. Sedangkan dari hasil analisis sifat fisika terhadap sampel dengan proporsi perbandingan tanah dengan oil sludge 1 : 1, porositasnya adalah 7,86\%. Pada sampel dengan proporsi oil sludge lebih kecil atau 3 : 1 porositasnya 18,18\%. Dengan demikian semakin banyak oil sludge yang ditambahkan ke dalam tanah maka semakin turun porositas, hal ini dapat berpengaruh pada proses degradasi yang dilakukan oleh mikroba. Mikroba membutuhkan porositas yang cukup tinggi untuk mendapatkan oksigen yang sangat penting selama degradasi hidrokarbon berlangsung. Oleh karena itu, semakin banyak kandungan oil sludge, semakin sulit degradasi terjadi.

Berdasarkan hasil uji sifat kimia, kandungan C-organik pada tanah yang digunakan selama penelitian adalah 0,32\%. Menurut Forster (1995) dalam Darliana (2009), C-organik penting untuk mikroorganisme, tidak hanya sebagai unsur hara, tetapi juga sebagai pengkondisi sifat fisik tanah yang mempengaruhi karakteristik agregat dan air tanah. C-organik tanah juga digunakan untuk menentukan dosis kompos yang akan diaplikasikan pada proses bioremediasi.

Sifat kimia lainnya yang dianalisis adalah KTK (kapasitas tukar kation). Berdasarkan hasil uji, KTK dari tanah yang digunakan selama penelitian adalah 17,30 me/100 gr. Kapasitas tukar kation (KTK) menunjukkan ukuran kemampuan tanah dalam menyerap dan dan mempertukarkan sejumlah kation. Makin tinggi KTK, makin banyak kation yang dapat ditariknya. Tinggi rendahnya KTK tanah ditentukan oleh kandungan liat dan bahan organik (BO) dalam tanah, dalam hal ini konsntrasi variabel bahan organic (BO) yang terkandung dalam tanah sebesar 0,55\%. Jika kadar KTK dalam tanah tinggi maka daya penyimpanan unsur hara akan tinggi. Tanah yang memiliki KTK yang tinggi akan menyebabkan lambatnya perubahan pH tanah. KTK tanah juga mempengaruhi kapan dan berapa banyak pupuk nitrogen (N-total), kalium dan pospat (P-total) yang harus ditambahkan ke dalam tanah.

Kandungan kimia lainnya yang diuji adalah konsentrasi N-total, Kalium dan P-total yaitu berturutturut sebesar 0,16\%; 0,05\%; 0,07\%. Unsur $\mathrm{N}$ dan $\mathrm{P}$ biasanya ada dalam jumlah terbatas di lingkungan. Unsur-unsur ini sangat penting untuk pembentukan sel. Unsur-unsur ini kadangkala harus ditambahkan untuk menunjang proses bioremediasi. Sedangkan berdasarkan sifat keasamannya, tanah masih berada pada kisaran normal dengan $\mathrm{pH}$ 6,54. 
Berdasarkan hasil analisis kimia terhadap oil sludge, konsentrasi C-organik yang terkandung dalam oil sludge sangat tinggi mencapai 45,22\%. Hal ini karena oil sludge memiliki kandungan minyak bumi yang masih sangat tinggi, sementara minyak bumi pada dasarnya adalah senyawa hidrokarbon. Karbon merupakan senyawa organik yang digunakan oleh mikoba heterotrof sebagai sumber energi untuk respirasi. Melalui proses respirasi mikroba dapat tumbuh dan bereproduksi (Cookson, 1995).

\section{b. Analisis Sifat Biologi}

Pengukuran variabel analisis biologi bertujuan untuk mengetahui keberadaan mikroba heterotrof. Secara mikrobiologis, terjadinya degradasi oil sludge dapat diduga dengan mengetahui pengurangan atau pertambahan jumlah sel mikroba pendegradasi setiap waktu. Untuk itu sel mikroba perlu dikultur dalam media kultur yang mengandung nutrisi sebagai sumber makan bagi mikroba. Analisis biologi dilakukan dengan metode pour plate dan NA (Nutrien Agar) sebagai media umum bakteri yaitu terdapat mikroba heterotrof dalam lumpur minyak (oil sludge) sebagai sampel penelitian.

\section{Analisis dan Pembahasan Hasil Sampling}

a. Analisis dan Pembahasan Uji Parameter $\mathrm{pH}$

Derajat keasaman $(\mathrm{pH})$ sangat berpengaruh terhadap kehidupan mikroorganisme dalam proses biodegradasi hidrokarbon. Sebagian besar biodegradasi oleh mikroorganisme terjadi pada pH netral. Nilai pH yang ekstrim, pada beberapa jenis tanah berpengaruh negatif terhadap kecepatan degradasi hirokarbon. Oleh karena itu pada penelitian ini perlu dilakukan uji parameter $\mathrm{pH}$, yang ditampilkan pada Tabel 5.

Tabel 5. Hasil pengukuran $\mathrm{pH}$ reaktor

\begin{tabular}{|c|l|c|c|}
\hline \multirow{2}{*}{ No } & \multirow{2}{*}{ Sampel } & \multicolumn{2}{|c|}{ Nilai pH } \\
\cline { 3 - 4 } & & Hari ke 0 & Hari ke 21 \\
\hline 1 & KI & 7.5 & 6 \\
\hline 2 & KII & 7 & 6 \\
\hline 3 & A & 7 & 6 \\
\hline 4 & B & 7 & 6 \\
\hline 5 & C & 7 & 5 \\
\hline 6 & D & 7 & 5 \\
\hline
\end{tabular}

Hasil pengukuran uji parameter sampel yang dilakukan 2 kali pengukuran selama 21 hari pengamatan menunjukan bahwa pada waktu pengukuran awal (0 hari) $\mathrm{pH}$ di tiap reaktor cenderung 
bersifat netral yaitu 7. Selanjutnya untuk t2 dan t3, semua reaktor menunjukkan penurunan nilai pH menjadi 6 dan 5. Penurunan $\mathrm{pH}$ tersebut diduga disebabkan oleh aktivitas mikroba yang membentuk metabolit-metabolit asam guna beradaptasi pada kondisi lingkungan baru. Kemungkinan lain penurunan $\mathrm{pH}$ terjadi karena terakumulasinya asam organik (terutama asam glukonat, piruvat, sitrat, dan suksinat) yang terbentuk dari metabolisme organik (Watkinson, 1980 dalam Nugroho, 2006).

Tingkat keasaman pH dapat diatasi dengan penambahan kapur pada sampel, dan penambahan sulfur jika pH sampel basa. Akan tetapi Departemen Konservasi Lingkungan Amerika menyatakan bahwa dalam beberapa penelitian melaporkan dengan penggunaan kapur dapat membahayakan mikroba, dan sebagai gantinya dapat digunakan magnesium.

\section{b. Analisis Uji Parameter TPH (Total Petroleum Hidrokarbon)}

Parameter TPH (Total Petroleum Hidrokarbon) diuji untuk mengetahui penurunan konsentrasi hidrokarbon dalam reactor. Pengamatan dilakukan selama 21 hari dengan 4 kali pengujian parameter TPH yang dilakukan tiap 7 hari. Aerasi dilakukan dengan cara melakukan pengadukan reaktor secara manual setiap hari. Pengadukan dilakukan untuk pertukaran oksigen yang dibutuhkan oleh mikroba yang hidup dalam kondisi aerob. Tabel 6 menunjukkan hasil pengujian konsentrasi total petroleum hidrokarbon (TPH).

Tabel 6. Hasil pengujian TPH sampel

\begin{tabular}{|c|l|c|c|c|c|}
\hline No & \multicolumn{1}{|c|}{ Sampel } & Hari ke 0 & Hari ke 7 & Hari ke 14 & Hari ke 21 \\
\hline 1 & KI & 9.23 & 7.77 & 7.8 & 6.66 \\
\hline 2 & KII & 5.95 & 6.05 & 5.78 & 5.75 \\
\hline 3 & A & 8.54 & 8.61 & 6.66 & 6.36 \\
\hline 4 & B & 10.69 & 8.99 & 7.38 & 6.79 \\
\hline 5 & C & 5.57 & 5.82 & 6.02 & 5.49 \\
\hline 6 & D & 6.48 & 6.43 & 6.35 & 5.45 \\
\hline
\end{tabular}

Tabel 6 menunjukan adanya penurunan konsentrasi hidrokarbon dalam waktu 3 minggu. Nilai konsentrasi TPH menunjukkan kecendrungan penurunan. Kecendrungan penurunan ini juga diperlihatkan oleh reaktor kontrol I. Hal ini bisa disebabkan oleh beberapa kemungkinan. Kemungkinan pertama, hal ini menunjukkan bahwa mikroba indigenous dalam oil sludge juga mempunyai kemampuan dalam menurunkan TPH walaupun tanpa penambahan kompos. Kemungkinan kedua, TPH turun bukan akibat aktivitas biologis, namun akibat volatilisasi komponen hidrokarbon rantai pendek misalnya. Volatilisasi diperkuat melalui pengadukan harian selama penelitian. Kemungkinan tersebut diperkuat dengan data reaktor yang ditambahi kompos. Secara hipotetik, reaktor C dan D seharusnya menunjukkan penurunan yang lebih baik karena 
proporsi tanah yang lebih banyak. Namun ternyata, trend penurunan yang cukup baik diperlihatkan oleh reaktor B yang memiliki proporsi oil sludge dan tanah yang sama. Hal ini juga diperlihatkan oleh reaktor A. Reaktor C dan D yang seharusnya menunjukkan hasil yang lebih baik, ternyata TPH-nya cendrung tetap atau turun namun tidak terlalu tinggi. Hal ini menunjukkan bahwa, mikroba indigenous dalam oil sludge berperan lebih banyak dalam penurunan TPH dibanding mikroba tanah ataupun kompos. Menurut Nugroho 2006, mikroba tidak dapat merombak senyawa hidrokarbon bisa terjadi karena mikroba yang ada dalam sampel belum pernah berhubungan dengan minyak bumi dalam proses evolusinya, dan kemungkinan juga mikroba tidak mempunyai enzim yang diperlukan dalam proses degradasi hidrokarbon. Mikroba tanah dan kompos belum pernah berhubungan dengan minyak bumi dalam proses evolusinya. Ketika dipaparkan dalam reaktor, mikroba-mikroba tersebut belum mampu mensintesis enzim katabolik yang sesuai untuk mendegradasi hidrokarbon dalam oil sludge, bahkan mungkin mati karena tidak mampu hidup dalam kondisi yang cukup toksik. Sebaliknya, mikroba indigenous telah terbiasa hidup dalam lingkungan toksik oil sludge dan akhirnya mampu mensintesa enzim katabolik untuk degradasi hidrokarbon. Hasil penelitian mungkin dapat berbeda bila waktu pengamatan diperpanjang misalnya, sehingga mikroba tanah maupun kompos dapat terbiasa dengan lingkungan toksik oil sludge dan lambat laun dapat mensintesa enzim untuk mendegradasinya.

Cookson (1995) menjelaskan senyawa hidrokarbon digunakan oleh mikroba sebagai sumber nutrisi dan sumber energi untuk melakukan metabolisme dan perkembangbiakan. Dan terjadinya proses degradasi senyawa hidrokarbon secara mekanisme berlandaskan pada prinsip bioremediasi dimana kelompok mikroba karbonklastik melakukan proses perombakan senyawa hidrokarbon dengan enzim pengoksidasi hidrokarbon, sehingga mikroba mampu mendegradasi senyawa hidrokarbon minyak bumi dengan memotong rantai hirokarbon menjadi lebih pendek. Selain itu, mikroba karbonklastik memiliki kemampuan untuk menempel pada hidrokarbon, kesanggupan memproduksi emulsifier, serta memiliki mekanisme untuk membebaskan diri (desorption) dari hidrokarbon. sintesis enzim pengoksidasi hidrokarbon dikode oleh kromosom mikroba dan plasmid yang termutasi. Mutasi kromoson dan plasmid mempengaruhi proses pemecahan molekul hidrokarbon. Karena senyawa hidrokarbon merupakan senyawa organik alami, maka banyak jenis mikroba yang berevolusi untuk menggunakan senyawa hidrokarbon. sehingga peningkatan populasi mikroba akan terjadi jika suatu lingkungan kaya akan kandungan hidrokarbon (minyak bumi). Hal tersebut terbukti pada penelitian ini dimana dengan proporsi lumpur minyak yang lebih banyak (sampel B) presentase penurunan kadar petroleum hidrokarbonnya lebih tinggi dibandingkan dengan proporsi lumpur minyak yang lebih sedikit. 
Pengaruh penambahan kompos terhadap pada campuran tanah dan oil sludge diperlihatkan pada Tabel 7.

Tabel 7. Pengaruh penambahan kompos terhadap TPH

\begin{tabular}{|c|l|c|c|c|}
\hline \multirow{2}{*}{ No } & \multirow{2}{*}{ Realitor } & \multicolumn{2}{|c|}{ Konsentrasi TPH (9) } & \multirow{2}{*}{$\begin{array}{c}\text { Penurunan } \\
\text { TPH }\end{array}$} \\
\cline { 3 - 4 } & & Hari ke 0 & Hari ke 21 & $26 \%$ \\
\hline 1 & KI & 9.23 & 6.66 & $2 \%$ \\
\hline 2 & KII & 5.95 & 5.75 & $22 \%$ \\
\hline 3 & A & 8.54 & 6.36 & $39 \%$ \\
\hline 4 & B & 10.69 & 6.79 & $1 \%$ \\
\hline 5 & C & 5.57 & 5.49 & $10 \%$ \\
\hline 6 & D & 6.48 & 5.45 & \\
\hline
\end{tabular}

Apabila dibandingkan, penambahan kompos 10\% memberikan angka penurunan TPH lebih baik dari yang 5\%. Hal ini menjelaskan bahwa kompos mampu berperan sebagai bulking agent yang dapat mempengaruhi transfer oksigen yang dibutuhkan mikroba. Bulking agent mampu memberikan porositas tanah lebih besar untuk pertukaran oksigen sehingga kebutuhan oksigen yang diperlukan mikroba dapat terpenuhi. Oksigen dibutuhkan oleh mikroba sebagai akseptor elektron dalam proses oksidasi hidrokarbon untuk menghasilkan energi dan reaksi enzimatis tertentu (Shuher dan Kargi, 1992 dalam Munawar dkk., 2007).

Banyak penelitian lapangan mengenai bioremediasi dengan penambahan nutrien organik, khususnya yang bersumber dari kompos menunjukkan hasil yang lebih efektif dalam menangani pencemaran dari minyak bumi. Hanya saja dalam prosesnya, kondisi dan komposisi penambahan nutrien yang paling optimal masih belum ditemukan. Kebanyakan mereka menyatakan bahwa jenis dan kosentrasi nutrien yang optimal sangat bervariasi tergantung properti minyak dan kondisi lingkungan (Venosa dan Zhu, 2003). Atagana, (2008) yang melakukan penelitian bioremediasi hidrokarbon terhadap pencemaran tanah dengan pupuk organik, menunjukan bahwa pupuk organik (pupuk kandang) yang dilengkapi dengan inokulasi secara efektif dapat menurunkan kandungan hidrokarbon yang tercemar di tanah dalam waktu empat bulan dengan penurunan yang fluktuatif setiap bulannya. Hal ini terjadi karena aktivitas pemotongan rantai hidrokarbon yang dilakukan oleh mikroba tidak merata, hanya mikroorganisme heterotropik yang mampu beradaptasi dan berkembang. Mikroorganisme mampu berkembang pada kondisi bertemperatur tinggi yang dihasilkan oleh pupuk organik (pupuk kandang). Sutherland dkk (1995) dalam Atagana, (2008) dan Ibekwe, dkk (2006) melakukan penelitian studi efek pemberian nutrien organik pada biodegredasi tanah yang terkontaminasi minyak mentah selama tujuh bulan. Hasil studi menunjukkan bahwa penambahan nutrien organik (terutama pupuk kandang ayam 90 g) akan lebih meningkatkan pemanfaatan hidrokarbon dimana nutrien organik berfungsi sebagai suplemen tambahan. 
Penelitian lainnya dilakukan oleh Munawar (2007) yang meneliti pengaruh penambahan nutrien organik pada bioremediasi tumpahan minyak mentah (crude oil) dengan metode biostimulasi di lingkungan pantai Surabaya Timur. Dalam waktu 30 hari, bioremediasi dengan metode ini menurunkan konsentrasi hidrokarbon sampai dengan 88,25\%. Hasil penelitian menunjukkan bahwa bahan organik memberikan indikasi yang baik untuk digunakan sebagai sumber nutrien.

Mengacu pada hasil-hasil penelitian sejenis di atas serta analisis terhadap peran mikroba indigenous, penambahan kompos pada bioremediasi lumpur minyak (oil sludge) memberikan hasil positif terhadap degradasi hidrokarbon. Kompos dalam penelitian ini, lebih berperan sebagai bulking agent serta mungkin sumber nutrisi tambahan, namun tidak berperan sebagai sumber mikroba pendegradasi. Dalam kurun waktu 21 hari, proses bioremediasi pada reaktor B dengan proporsi tanah dan oil sludge yang sama mampu mendegradasi hidrokarbon (TPH) hingga 39\% dari konsentarsi awal TPH. Prosentasi penurunan TPH dapat menjadi lebih tinggi apabila waktu penelitian diperpanjang.

\section{c. Analisis Uji Parameter TPC (Total Plate Count)}

Uji Total Plate Count (TPC) dilakukan untuk melihat aspek mikrobiologis dari setiap reaktor. Melalui uji ini, jumlah total mikroba yang ada dalam setiap reaktor dihitung. Pengujian parameter jumlah total bakteri (TotalPlate Count) dilakukan dengan 4 kali pengambilan sempel setiap 7 hari. Tabel 8 menunjukkan hasil pengukuran TPC.

Tabel 8. Hasil Uji TPC

\begin{tabular}{|c|c|c|c|c|}
\hline \multirow{2}{*}{ Sampel } & \multicolumn{4}{|c|}{ Rata-rata TPC (koloni) } \\
\cline { 2 - 5 } & Hari lie 0 & Hari ke 7 & Hari ke 14 & Hari lee 21 \\
\hline KI & 305 & 450 & 990 & 3.145 \\
\cline { 2 - 5 } KII & 540 & 415 & 1.405 & 1.690 \\
\cline { 2 - 5 } A & 30 & 115 & 1.125 & 3.105 \\
\cline { 2 - 5 } B & 300 & 175 & 1.005 & 2.815 \\
\cline { 2 - 5 } C & 260 & 55 & 815 & 1.110 \\
\cline { 2 - 5 } D & 60 & 80 & 1.010 & 1.530 \\
\hline
\end{tabular}

Aktivitas mikroba dalam reaktor melibatkan 3 kelompok mikroba yaitu kelompok mikroba indigenous yang telah ada dalam lumpur minyak (oil sludge), kelompok mikroba hasil pembenihan (inokulasi), serta kelompok mikroba yang berasal dari tanah serta kompos. Keterlibatan dari ke 3 kelompok mikroba tersebut memiliki peran yang penting dalam proses pendegradasi hidrokarbon.

Secara umum, TPC menurun pada minggu pertama setelah inokulasi. Kemungkinan pada kurun waktu tersebut, mikroba berada pada fase adaptasi. Mikroba yang tidak dapat menyesuaikan diri 
terhadap lingkungan yang baru mengalami kematian. Namun pada minggu-minggu berikutnya, mikroba yang mampu bertahan sudah beradaptasi dan berkembang biak dengan cepat pada mingguminggu berikutnya. Hal ini diperkuat dengan data pada tabel. Nilai TPC dari reaktor kontrol I dan reaktor A dan B jauh lebih tinggi dari reaktor lain. Reaktor-reaktor tersebut memiliki proporsi oil sludge dan tanah yang sama, artinya lebih banyak dari reaktor lain. Oleh karena itu, mikroba indigenousnya juga lebih banyak. Karena mikroba indigenous telah terbiasa dengan kondisi toksik oil sludge, mikroba ini mampu bertahan hidup dan berkembang biak dalam kondisi lingkungan reaktor.

Data di atas juga menunjukkan bahwa penambahan kompos tidak terlalu mempengaruhi perkembangan mikroba. Mikroba dapat berkembang dengan baik tanpa penambahan kompos. Hal ini ditunjukkan oleh data reaktor kontrol I yang justru tanpa penambahan kompos memberikan nilai TPC tertinggi. Sementara itu reaktor B yang memiliki kandungan kompos lebih tinggi justru nilai TPC-nya lebih rendah dari reaktor A yang komposnya lebih sedikit. Data ini juga menguatkan analisis bahwa kompos tidak memberikan sumbangan mikroba terhadap proses yang berlangsung. Penambahan kompos memberi pengaruh pada proses degradasi yang dilakukan oleh mikroba indigenous dalam oil sludge terutama sebagai bulking agent.

Menurut Cookson (1995) disamping mengandung unsur nitrogen, fosfor, dan kalium, kompos juga mengandung ion-ion logam yang dapat berfungsi sebagai kofaktor. Kofaktor merupakan kombinasi senyawa protein dan non-protein yang dapat memberikan aktivitas katalitik pada enzim yang diproduksi oleh bakteri.

Di tanah, kandungan minyak bumi dapat terserap oleh pertikel-partikel tanah dan materi tumbuhan lainya. Kondisi ini mempengaruhi persebaran jumlah koloni mikroba pendegradasi hidrokarbon, semakin besar luas lingkungan yang mengandung minyak bumi, semakin banyak koloni yang tumbuh sehingga proses biodegradasinya akan semakin cepat. (Leahy dan Colwell, 1990). Kondisi yang sebaliknya terjadi pada proporsi perlakuan sampel reaktor C dan D dengan proporsi campuran tanah lebih banyak ( $3: 1$ ) Hal ini yang ditunjukkan rendahnya jumlah total bakteri (TPC/Total Plate Count) pada sample reaktor C dan D.

Pada TPH yang rendah tidak membuat mikroba mati tetapi dapat membatasi biodegradasi karena persediaan karbon yang sedikit untuk pertumbuhan mikroba (Admon et al., 2001 dalam Chokshi, 2003). Mikroba pendegradasi hidrokarbon (minyak bumi) banyak tersebar di tanah, laut dan air tawar. Mikroba tersebut sebagian besar adalah bakteri. Hal yang sama terjadi pada penelitian yang dilakukan oleh Venosa, dkk (2002), bahwa populasi mikroba yang berpotensi mendegradasi minyak bumi dalam perairan yang tidak tercemar hanya sekitar 1\% dari total populasi mikroba heterotrofik, 
sedangkan pada perairan tercemar tumpahan minyak, populasi mikroba pendegradasi hidrokarbon meningkat menjadi 10\%. Adanya peningkatan populasi mikroba terjadi karena adanya donimasi selektif mikroba yang mampu mengubah senyawa hidrokarbon menjadi sumberkarbon dan energi. Adanya senyawa hidrokarbon menghasilkan pengayaan secara alami dengan tumbuhnnya berbagai jenis mikroba. Adapun jenis mikroba/bakteri pengguna hidrokarbon, diataranya Achromobacter, Acinetobacter, Aeromonas, Alcaligenes, Arthrobacter, Bacillus, Benecdea, Brevibacterium, Corynebacteriu, Flavobacterium, Methylobacterium, Methylococcus, Methyloctis, Methylomonas, Methylosinus, Micromonospora, Mycrobacterium, Nocardia, Pseudomonas, Sprillum, Vibrio (Atlas dan Bartha, 1985). Terdapat lebih dari sekitar 100 spesies mikroba yang mampu menggunakan hidrokarbon, dan diantarnya terdapat hubungan saling menguntungkan. Mikroba yang hidup dan banyak berperan di lingkungan yang mengandung hidrokarbon adalah bakteri, sedangkan kehadiran jenis lain yang tidak terlalu mendominasi tetapi cukup berperan yaitu fungi, ragi, alga dan aktinomisetes.

Mekanisme pada penelitian bioremediasi lumpur minyak (oil sludge)dengan penambahan kompos sebagai bulking agent pada prinsipnya bergantung pada jumlah mikroba yang cukup untuk mendegradasikan minyak bumi melalui jalur metabolisme mikroba yang mampu memproduksi enzim yang dapat mendegradasi bahan kimia beracun sebagai senyawa sasarannya. Penambahan kompos sebagai bulking agent merupakan komponen penting yaitu sebagai penggembur yang berperan dalam proses oksidasi yang dilakukan oleh mikroba serta tambahan nutrien yang cocok untuk pertumbuhan dan perkembangan mikroba.

\section{d. Uji Parameter Kadar Air}

Pengujian parmeter kadar air bertujuan untuk mengontrol jumlah air yang ada pada reaktor. Karena air dapat mempengaruhi keberadaan kontaminan, transfer gas, tingkat toksisitas kontaminan, perpindahan dan pertumbuhan mikroorganisme. Kadar air yang terlalu rendah dapat membatasi pergerakan mikroba dan menghambat metabolisme sel mikroba. Kadar air yang diukur dapat berdasarkan berat material basah (berat basah) atau material kering (berat kering), perhitungan tersaji dalam lampiran. Berdasarkan hasil pengamatan dan uji, pada Tabel 9 menunjukkan hasil uji kadar air yang dilakukan dengan 2 kali pengujian parameter selama 21 hari penelitian.

Cookson (1995) menyebutkan bahwa kadar air optimum bagi proses bioremediasi guna transfer gas berkisar antara 25-35\%. Pada analisis sifat kimia tanah dan oil sludge kadar airnya mencapai 2,96\% dan 4,72\%. Sedangkan berdasarkan tabel analisis sampel pengujian parameter kadar air (Tabel 9) 
terjadi penurunan presentasi kadar air, hal ini dapat disebabkan karena proses aerasi/ pengadukan yang dilakukan setiap hari selama penelitian yang menyebabkan penguapan. Menurut Doerffer dalam Nugroho (2006), senyawa hidrokarbon akan mengalami degradasi secara alami karena faktor-faktor lingkungan, meskipun laju degradasi berjalan lambat. Hal tersebut meliputi penguapan, teremulsi dalam air, teradsorpsi pada partikel padat, tenggelam dalam perairan serta mengalami biodegradasi oleh mikroba. Secara tidak langsung kadar air yang mengalami proses penguapan dapat menurunkan konsentrasi hidrokarbon, terutama senyawa berberat molekul rendah yang biasanya bersifat toksik.

Tabel 9. Hasil uji kadar air

\begin{tabular}{|l|l|c|c|}
\hline \multirow{2}{*}{ No } & \multirow{2}{*}{ Sampel } & \multicolumn{2}{|c|}{ Rata-rata Kadar Air (\%) } \\
\cline { 3 - 4 } & & To & T3 \\
\hline 1 & KI & 0.23 & 0.09 \\
2 & KII & 0.43 & 0.18 \\
3 & A & 1.39 & 0.28 \\
4 & B & 1.92 & 0.27 \\
5 & C & 2.42 & 0.20 \\
6 & D & 2.63 & 0.18
\end{tabular}

e. Analisis Gas Chromatography (GC)

Analisis Uji Parameter GC dilakukan di dilaboratorium penelitian dan pengujian terpadu (LPPT) Universitas Gajah Mada Jogjakarta. Analisis Uji GC (Gas Chromatography) bertujuan untuk melihat kelimpahan senyawa selama proses penelitian berlangsung. Selama proses bioremediasi berlangsung, mikroba memotong-motong serta mentransformasikan komponen hidrokarbon yang berantai panjang sehingga akan memperlihatkan perubahan komposisi fraksi hidrokarbon penyusunnya. (Sharpley, 1996 dalam Nugroho 2006).

Prinsip kerja GC yaitu memisahkan senyawa organik dengan meneruskan arus gas melalui fase diam. Waktu tambat (waktu retensi) pada GC menunujukan identitas senyawa yang dapat memberikan informasi kualitatif, yaitu ada tidaknya senyawa tertentu dan secara kualitatif dapat menunjukan banyaknya masing-masing senyawa dalam suatu campuran. Penggunaan alat GC menghasilkan pemisahan senyawa-senyawa di dalam fraksi hidrokarbon sehingga degradasi dapat dideteksi dengan melihat tumbuhnya atau hilangnya berbagai puncak yang merupakan identitas senyawa-senyawa hidrokarbon (Sumar, 2006).

Sampel yang dianalisis dengan GC berasal dari reaktor B yang menunjukkan aktivitas degradasi terbaik berupa penurunan TPH paling tinggi. Hasil analisis GC diperlihatkan pada Gambar 3.

Pada sampel oil sludge, muncul 234 puncak yang kurang lebih mewakili jumlah senyawa hidrokarbon penyusunnya. Hasil analisis terhadap sampel B, memperlihatkan penurunan jumlah 
puncak yang muncul menjadi 205. Jumlah tersebut kurang lebih menunjukkan senyawa-senyawa yang masih tersisa ataupun yang muncul. Berkurangnya jumlah puncak yang muncul dapat diartikan disebabkan karena menguapnya senyawa-senyawa hidrokarbon rantai pendek atau juga dapat menunjukkan aktivitas biodegradasi oleh mikroba. Analisis GC juga memperlihatkan penurunan kandungan hidrokarbon dari 4,71\% menjadi 1,67\%.

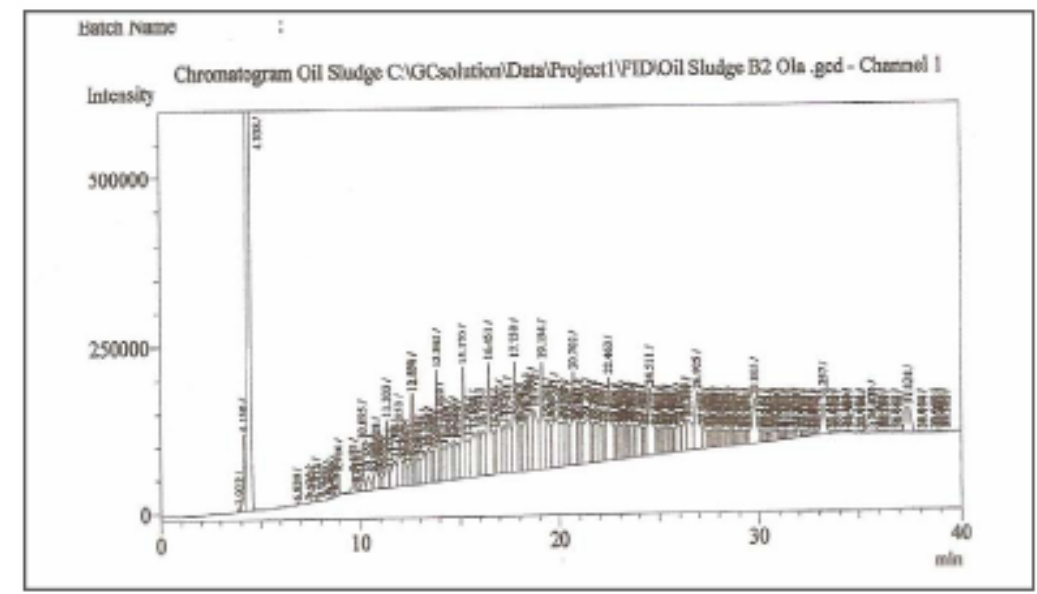

Gambar 3. Chromatogram GC sampel

\section{Kesimpulan dan Saran}

\section{Kesimpulan}

Dari hasil penelitian dan analisis data dapat diambil beberapa kesimpulan, yaitu:

a. Pada bioremediasi oil sludge yang berasal dari PT Pertamina Cilacap menunjukkan bahwa proporsi campuran terbaik antara tanah dan oil sludge adalah $1: 1$ dengan efisiensi penurunan TPH mencapai 39\%.

b. Penambahan kompos memberikan pengaruh positif pada proses bioremediasi dimana kompos lebih berperan sebagai bulking agent dan sumber nutrisi tambahan dibanding sebagai penyumbang mikroba pendegradasi.

c. Penambahan kompos $10 \%$ (b/b) memberikan hasil lebih baik dari yang $5 \%$ karena porositas yang diberikannya lebih besar sehingga transfer oksigen selama proses menjadi lebih baik.

\section{Saran}

Beberapa saran untuk penelitian lanjutan diantaranya sebagai berikut:

a. Penelitian dilakukan dalam jangka waktu lebih panjang sehingga efisiensi maksimum proses dapat diketahui. 
b. Diperlukan analisis Gas Chromatography (GC) yang dilengkapi dengan penyajian nama senyawa (GC-MS) yang terkandung dalam sampel yang diujikan sehingga senyawa yang hilang dan muncul dapat dideteksi.

c. Melakukan penelitian lanjutan dengan memperbanyak jumlah variasi perlakuan sehingga dapat ditemukan variasi perlakuan yang lebih efektif untuk proses bioremediasi hidrokarbon.

\section{Daftar Pustaka}

Atagana, HI. (2008). Compost Bioremediation of Hydrocarbon - Contaminated Soil Inoculated with Organic Manure. African Journal of Biotechnology, Vol. 6 (13), pp. 1529-1535, 16 May 2008.

Chokshi, Bunkim G. (2003). Microbial Biodegradation of Hydrocarbons In Petroleum Sludge Wastes. www.ceenve3.civeng.calpoly.edu.

Cookson, J. T, Jr. (1995). Bioremediation Engineering Design \& Application. McGraw Hill, Inc. USA.

Darliana. (2009). Pengaruh Jenis Bokashi Terhadap Bobot Isi, C-Organik, dan KTK Tanah, serta Hasil Daun Teh pada Andosols Asal Gambung. www.p4tkipa.org.

Effendi, AJ. (1999). Isolation and Characterization of 2,3-Dichloro-1-Propanol-Degrading Bacterium: Agrobacterium sp. NHG3. PhD Thesis, University of Wales, Cardiff, UK.

Gaudy, A., Gaudy, E. (1980). Microbiology for Environmentar Scientist and Engineer. Mc-Graw Hill Book Co.

Greenberg A., Clesceri, L, Eaton, A. (1992). Standard Methods $18^{\text {th }}$ edition for The Examination of Water and Waste Water, American Public Health Association, Washington.

Sumar, H. (2006). Kimia Pemisahan Metode Kromatografi dan Elektroforesis Moderen. Rosdakarya. Bandung.

Leahy and Colwell. (1990). Microbial Degradation of Hydrocarbons In the Environment. Department American Society of Microbiology, University of Maryland Vol. 54, No. 3. http://mmbr.asm.org/cgi/reprint/pdf.

Munawar, dkk. (2007). Bioremediasi Tumpahan Minyak dengan Metode Biostimulasi Nutrien Organik di Lingkungan Pantai Surabaya Timur. Berk. Penel. Hayati: 13 (91-96).

Nugroho, A. (2006). Bioremediasi Hidrokarbon Minyak Bumi. Graha Ilmu. Yogyakarta.

Nugroho, A. (2006). Bioremediasi Sludge Minyak Bumi dalam Skala Mikroskopis: Simulasi Sederhana Sebagai Kajian Awal Bioremediasi Land Treatment. Makara Teknologi, Vol. 10, No. 2, November 2006:82-89.

Rump, H.H., Weinheim, H.K. (1992). Laboratory Manual for The Examination of Water, Wastewater and Soil. VCH.

Ubochi, K.C., Ibekwe, V., and Ezeji, E. (2006). Effect of Inorganic Fertilizer on Microbial Utilization of Hydrocarbons on Oil Contaminated Soil. www.academicjournals.org/AJB.

Wesley, L D. (1977). Mekanika Tanah. Jilid 1. Badan Penerbit Pekerjaan Umum. Jakarta.

Venosa, AD., Zhu, X. (2003). Biodegration of Crude Oil Contaminating Marine Shoreline and Freshwater wetland. Spill Science and Tecnology Bulletin, vol 8(2). 